\title{
Statistical analysis of the structure and dynamics of the number of students in public education over the past two academic years from Bacau
}

\author{
Eugenia Harja, „Vasile Alecsandri” University of Bacau, Romania
}

\begin{abstract}
Bacau public university, represented by the "Vasile Alecsandri" University from Bacau, is the third such center in the region. With more than 7400 students, it represents $7.5 \%$ of North-East Region and $1.1 \%$ of the total country. The number of students registered in the academic year 2009/2010 a positive dynamic in total (11.9\%, 792 students) than the previous year. For the university studies, the number of students increased by 5\%, dynamics above average recording the Faculty of Sciences (58.3\%), Faculty of Movement, Sports and Health (15.1\%), Faculty of Economics (+ 13.3\%).

The students in the academic program stand for $73.5 \%$ of the total, from the masters programs $15.2 \%$, from the postgraduate masters $9.2 \%$, other postgraduate courses $1.5 \%$ and $0.6 \%$ doctoral school. In the last two years, over 3200 graduate students have completed the university.
\end{abstract}

\section{Keywords}

Students, graduates, bachelor degree, university master, postgraduate master, Phd, dynamic

JEL Codes: I21, C10

The university education from Bacau grew increasingly after the $90 \mathrm{~s}$, being outlined as a center of increasingly value to train future specialists needed for the local labor market and beyond. Public university education had in the academic year 2008/2009 a share of almost $70 \%$ of the total and at the beginning of 2009/2010 there were enrolled 7442 students in all forms of education, $11.9 \%$ more than the previous year. A higher dynamics was recorded at the students that pay the university tax, where the number of students increased by $15.7 \%$. According to the latest published statistics, the public university education from Bacau ranked third in the Northeast Region as students number, after Iasi and Suceava and ranks 17 th in the country.

Total number of students enrolled in university licensing programs this year increased by $5 \%$ (263 students) as compared to the beginning of the previous academic year, representing $73.5 \%$ of all students. The only decline was recorded in the Faculty of Engineering ( $\%-14.9$ respectively -313 students), the situation is due to the inclusion in the previous academic year of the $5^{\text {th }}$ year for the last promotion of education before implementing the Bologna process. 
Table 1. Students enrolled in the license programs, dynamic in the last two years

\begin{tabular}{|c|c|c|c|c|}
\hline & \multicolumn{2}{|c|}{$\begin{array}{c}\text { Students enrolled at the } \\
\text { beginning of academic year }\end{array}$} & \multirow{2}{*}{$\begin{array}{c}\text { Dynamics }(+/ \\
\%)\end{array}$} & \multirow{2}{*}{$\begin{array}{c}\text { Dynamics }(+/ \\
\text { students })\end{array}$} \\
\hline & $2008 / 2009$ & $2009 / 2010$ & & \\
\hline License all university students, of which: & 5212 & 5475 & 5,0 & 263 \\
\hline - Faculty of Letters & 553 & 593 & 7,2 & 40 \\
\hline - Education Day & 553 & 593 & 7,2 & 40 \\
\hline - Faculty of Engineering & 2104 & 1791 & $-14,9$ & -313 \\
\hline - Education Day & 2104 & 1791 & $-14,9$ & -313 \\
\hline $\begin{array}{l}\text { - Faculty of Movements Sciences, Sports and } \\
\text { Health }\end{array}$ & 677 & 779 & 15,1 & 102 \\
\hline - Education Day & 571 & 568 & $-0,5$ & -3 \\
\hline - education with reduced frequency & 106 & 211 & 99,1 & 105 \\
\hline - Faculty of Sciences & 314 & 497 & 58,3 & 183 \\
\hline - Education Day & 292 & 413 & 41,4 & 121 \\
\hline - education with reduced frequency & 22 & 84 & 281,8 & 62 \\
\hline - Faculty of Economics & 1492 & 1691 & 13,3 & 199 \\
\hline - Education Day & 869 & 903 & 3,9 & 34 \\
\hline - înv. Frecvență redusă & 41 & 176 & 329,3 & 135 \\
\hline - Education the Distance Learning & 582 & 612 & 5,2 & 30 \\
\hline Teacher Training Department & 72 & 124 & 72,2 & 52 \\
\hline
\end{tabular}

(Source: calculation after D.J.S. Bacau data)

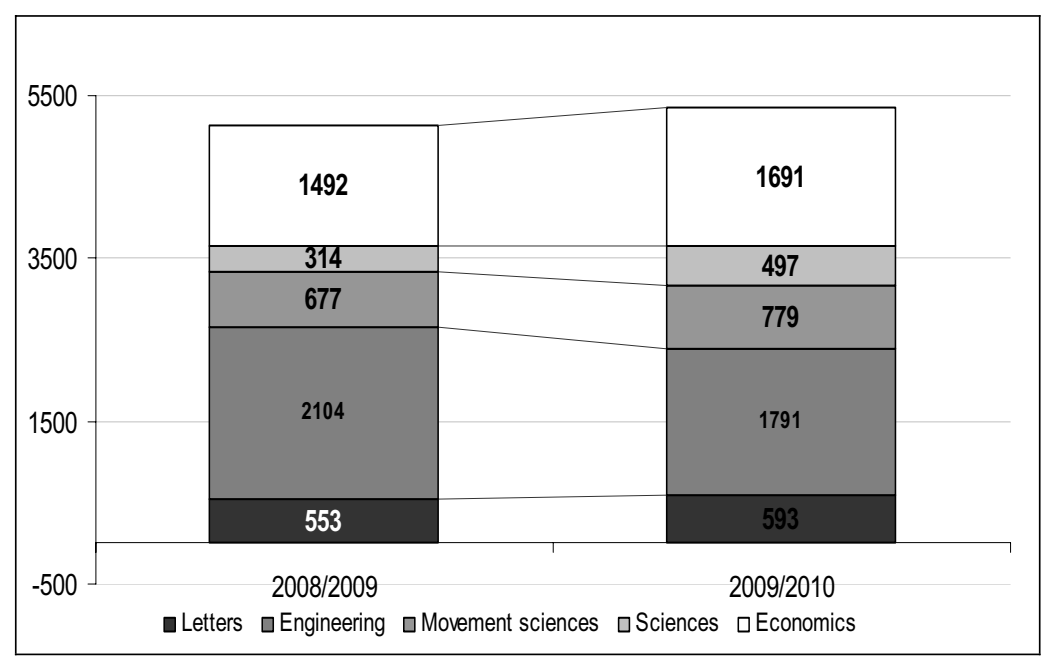

Figure 1. Students enrolled in the license programs, at the beginning of the university year, by faculties

Source: calculations after D.J.S data

In the Bologna cycle, of 4 years, it remained constant the number of students enrolled in Mechatronics specialization, and it increased in the specializations: engineering and quality management $(82.1 \%$, 23 students), the Industrial Energy (34.2\% +40 students), the Food Engineering $(7.2 \%, 17$ students). The number of students enrolled in other majors decreased and for the Energy Management and Industrial design was no more organized a series in the first year. In the Faculty of Letters, the total number of students enrolled increased by $7.2 \%$ ( +40 students), but decreases with $54.8 \%$ of the number enrolled in history profile. The Faculty of Science Movement, Sports and Health recorded increases by $15.1 \%$ (102 students), an increase achieved through education made solely on account of low frequency university, while the number of students in the form of daily university decreased slightly (3 students). In the therapy specialization, the number of students enrolled increased by $6.1 \%$ $(+18$ students) in comparison to the beginning of the previous year and physical education 
and sports increased by $5.5 \%$ ( +21 students). Two new specializations have been established, Occupational Therapy (24 students enrolled) and sports and motor performance (39 students enrolled).

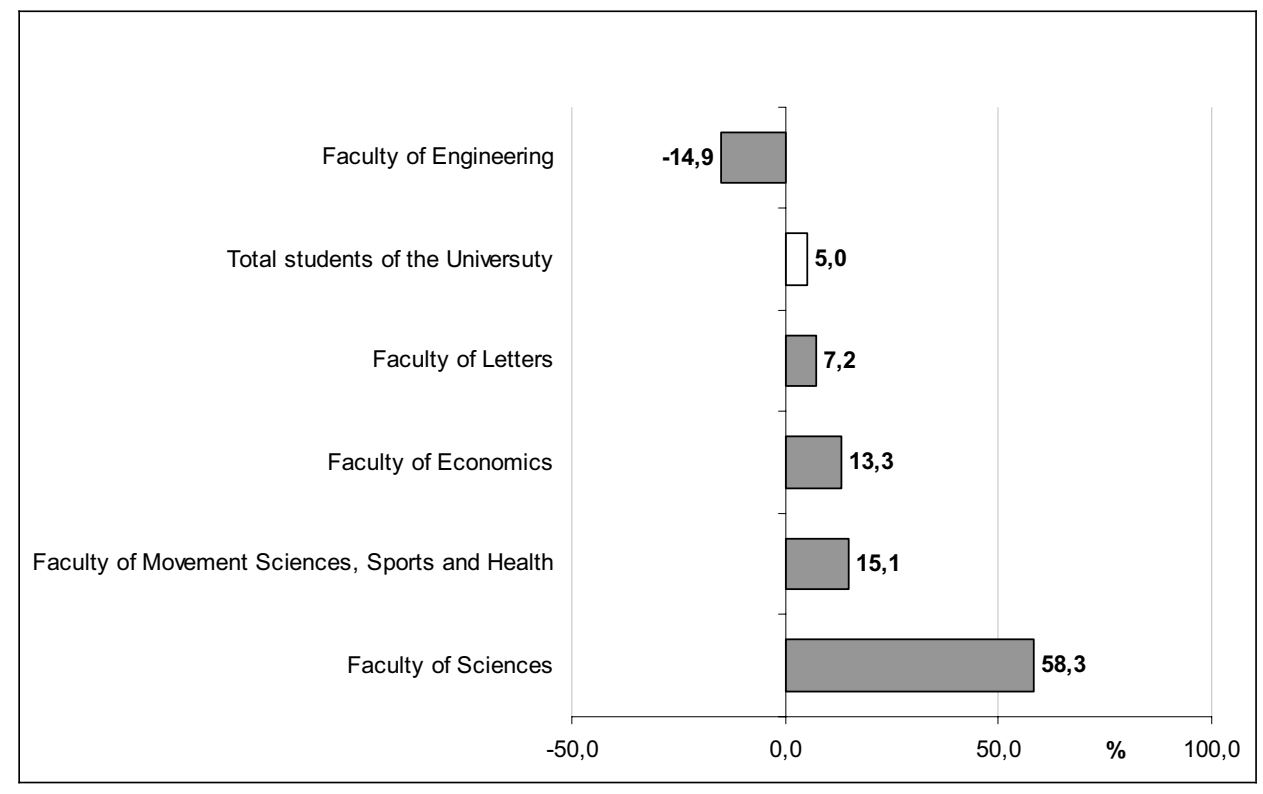

Figure 2. Dynamics of the students enrolled in the license programs at the beginning of the university year $2009 / 2010$ unlike $2008 / 2009$ ) $+/-\%$

Source: calculations after D.J.S data

In the Faculty of Sciences on the total number of students enrolled increased by $58.3 \%$ (+183 students), $66.1 \%$ of the increase is on account of the form of daily teaching and $33.9 \%$ FR. For the part time teaching, the number of students enrolled increased by 3.8 times $(+62$ students). Increases were recorded in all specialties: Informatics with $47.6 \%$ (69 students), Mathematics with $40 \%$ ( +20 students) and Biology with $9.2 \%$ ( +11 students). It was also formed a new specialization, ecology and environment, with a total of 83 students enrolled at the beginning of the university year. Due to the above, the Faculty of Sciences experienced in this regard the highest relative dynamics, after DPPD. For the Faculty of Economics was recorded an increase in total number of students enrolled 13.3\% $(+199$ students), $67.8 \%$ of the growth being achieved at the expense of the reduced frequency education of Accounting and Management Information Systems specialization, $17.1 \%$ due to daily education, $15.1 \%$ due to the Distance Learning Marketing specialization. The Faculty of Economic Sciences had at the beginning of the year $53.4 \%$ of students enrolled for daily education, $36.2 \%$ for ID and $10.4 \%$ for FR. It was also formed a new specialization, Business Administration, with a total of 83 students enrolled in early, and the two older specializations have made gains on account ID / FR, respectively $14.6 \%$ in Accounting and Administration (+76 students) and $4.1 \%$ in Marketing (+40 students). For the Teacher Training Department, the number of students enrolled increased by $72.2 \%(+52$ students). On forms of funding, the budgeted number of students decreased by $4.8 \%$ on all university, a decrease only because of the disappearance of the fifth year of the Faculty of Engineering. Instead it increased by $11 \%$ the number of students paying university tax. 


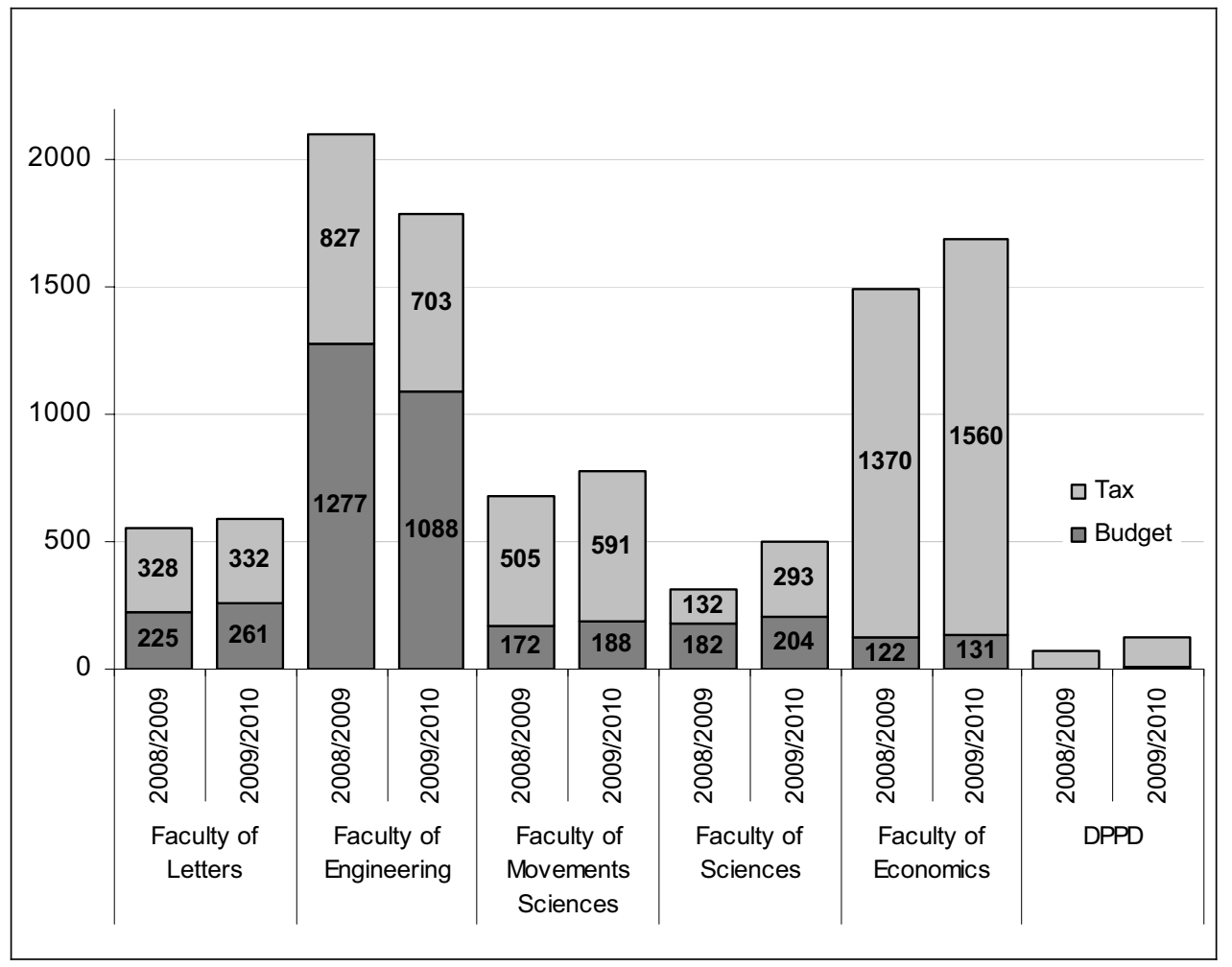

Figure 3. Students enrolled in license education, by financing forms Source: calculations after D.J.S data

Of all students in budget education in 2009/2010 for the license education, the Faculty of Engineering holds $57.8 \%, 13.9 \%$ the Faculty of Letters, Faculty of Sciences $10.8 \%, 10 \%$ the Faculty of Movement, Health and Sports, the Faculty of Economics 7\% and 0.6\% DPPD. Of all students paying fee, $43.4 \%$ are owned by the Faculty of Economics, $19.6 \%$ by the Faculty of Engineering, $16.5 \%$ by the Faculty of Movement, Sports and Health, $9.2 \%$ by the Faculty of Letters, $8.2 \%$ by the Faculty of Sciences and $3.1 \%$ by the Faculty of DPPD. Overall, it can be said that the number of students enrolled at the "Vasile Alecsandri " University from Bacau in the license programs is high compared to the economic conjuncture and the target population in the process of decline.

The total number of students enrolled in the university to university master's programs this year increased 2.6 times $(+697$ student), due to the start of these programs also in the Faculty of Engineering, and also because of the existence for the first time of two studies in such programs for all other faculties. (See Annexes 5 and 6). At all colleges, it increases the number of graduates because of this issue.

For all the students enrolled in the master programs at the beginning of this academic year, $36.5 \%$ were graduates from the Faculty of Economics, $20 \%$ from the Faculty of Movement, Sports and Health, 16.8\% from the Faculty of Engineering and 13.4\% from the Faculty of Letters and $13.3 \%$ from the Faculty of Sciences. 


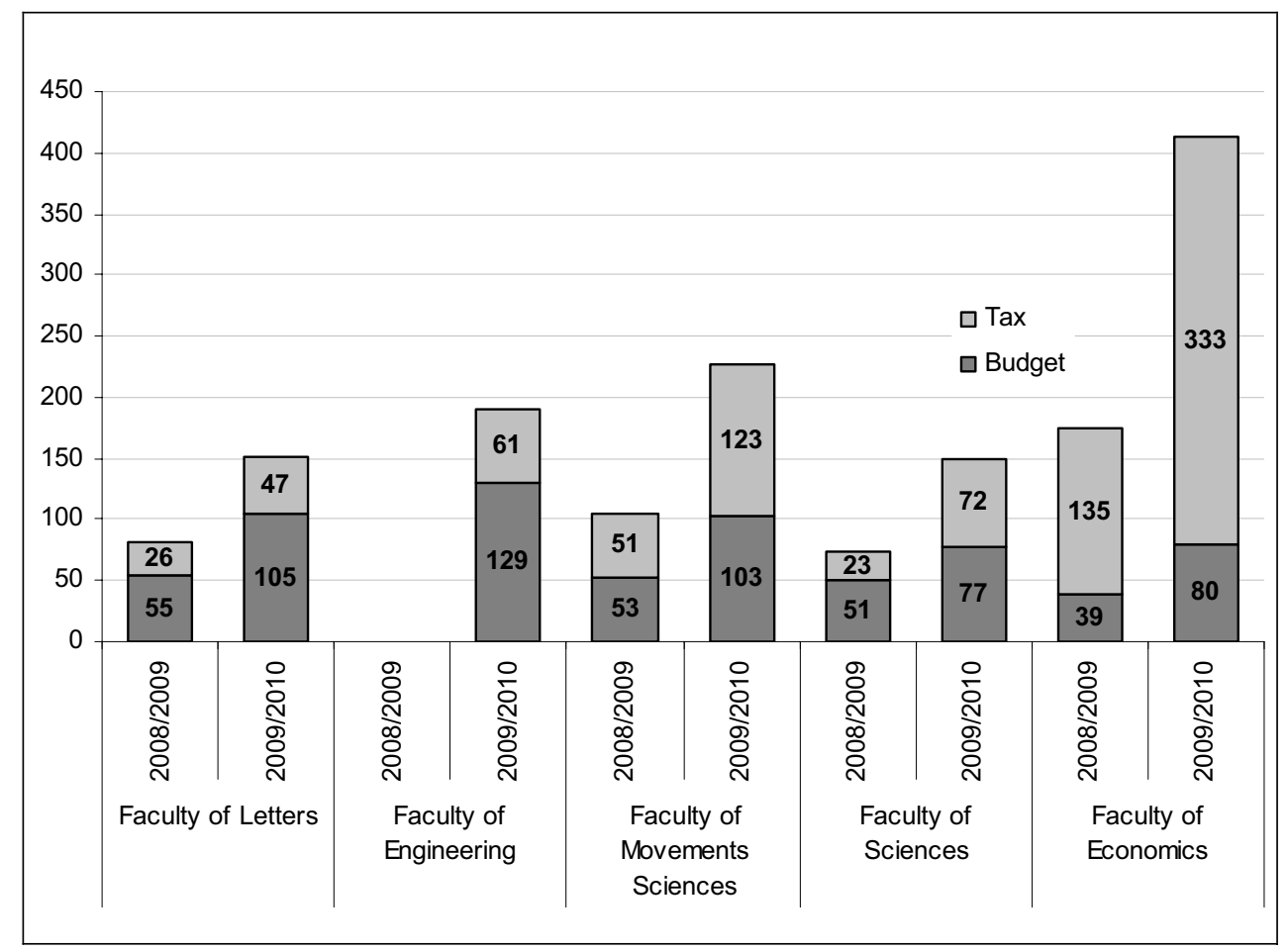

Figure 4. Students enrolled in university master programs, by financing forms Source: calculations after D.J.S data

The number of master students benefiting from budget funds increased almost 2.5 times in total (+296 students), mainly due to the emergence of the first year of studies at the Faculty of Engineering, as well as of the second year of the other faculties (See Annex 6). Increases by 2.7 times were observed also at master students in the tax regime ( +401 students) for total university. The highest dynamic in this regard was registered at the Faculty of Economics ( + 2.5 times, +198 students).

The total number of students enrolled in the university postgraduate Masters programs this year decreased by $20 \%$ (-172 students), all the faculties recorded reductions except the Faculty of Economics in which they increased by $5 \%(+12$ students). The largest decreases in both relative and absolute size, have been registered by the Faculty of Letters (-73\%, -58 students) and by the Faculty of Movement, Sports and Health (-49\%, 96 students).

These decreases were mainly due to the emergence of new programs from the 2008/2009 academic type master Bologna, which offset the decrease in students enrolled in the postgraduate master's programs, the new Bologna license cycle graduates type not being supported by the law postgraduate masters programs . 


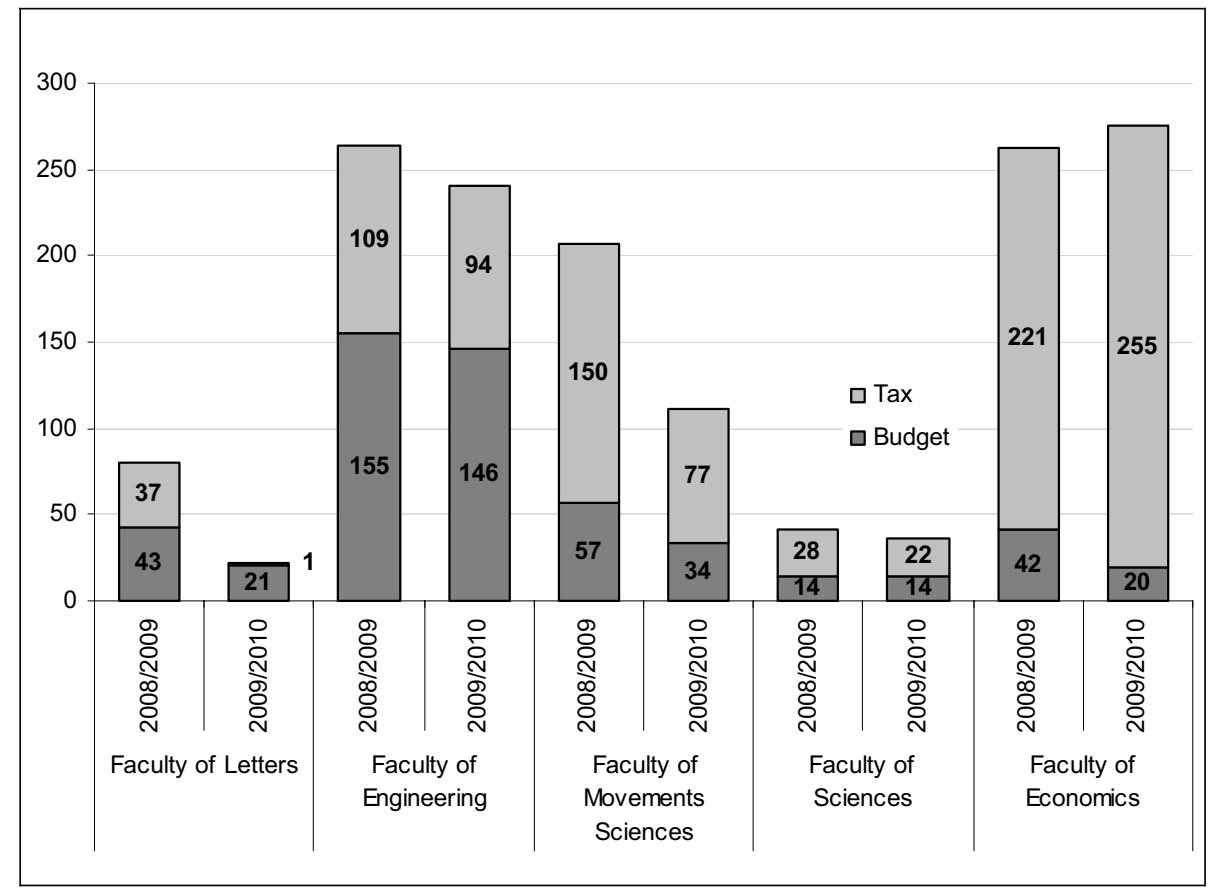

Figure 5. Students enrolled in the postgraduate master programs, by financing forms Source: calculations after D.J.S data

The total number of doctoral students enrolled in the university increased in total by $59 \%$ $(+16 \mathrm{PhD})$, the budgeted seats increasing of 2.2 times $(15 \mathrm{PhD})$, and the tax places increasing by $7 \%(+\mathrm{a} P \mathrm{PD})$. All doctoral students belong to the Faculty of Engineering, the other departments having no authority to IOSUD.

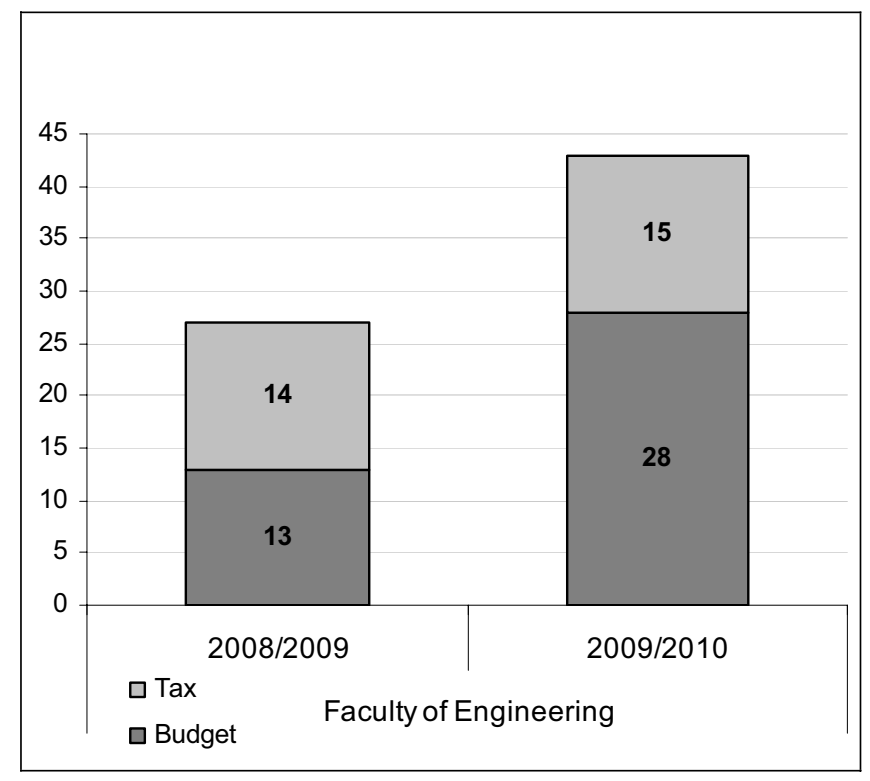

Figure 6. Students enrolled in the doctoral programs, by financing forms Source: calculations after D.J.S data 
The number of students for all forms of education (bachelor, university master, postgraduate master, and postgraduate training courses and doctoral) increased from 6650 students in $2008 / 2009$ academic year, to 7442 students in the $2009 / 2010$ academic year $(11,9 \%,+792$ students). The most relative dynamic is met in the Faculty of Economic Sciences $(58.6 \%,+252$ students) and the most absolute dynamic is met in the Faculty of Sciences (450 students, equivalent to $23.3 \%$ ). The only college to have been dropped by all is the Faculty of Engineering (-5.7\%, representing -143 students). The decrease was observed bothe at the budget students $(-3.7 \%,-54$ students) and at the fee-paying students $(-8.3 \%,-89$ students). A decrease was also registered at the number of fee-paying students $(-2.8 \%,-11$ students $)$ at the Faculty of Letters. The number of 7442 students in all forms of education points out clearly the university's increasing development in this regard. If we take into account the economic crisis and the demographic decline, factors acting generally in reducing the number of students, the university development appears stronger.

Statistical data shows that the number of graduates in 2009 was 1.532 for total university, decreasing by $7.7 \%$ (-131 graduates). This decrease was due exclusively to the completion in the previous year of the second generation of students from the license cycle, respectively of 4 years and 3 years for the Bologna type, in all specialties, except the faculty of engineering, in which this situation occurred this year and the number of graduates increased 2.2 times.

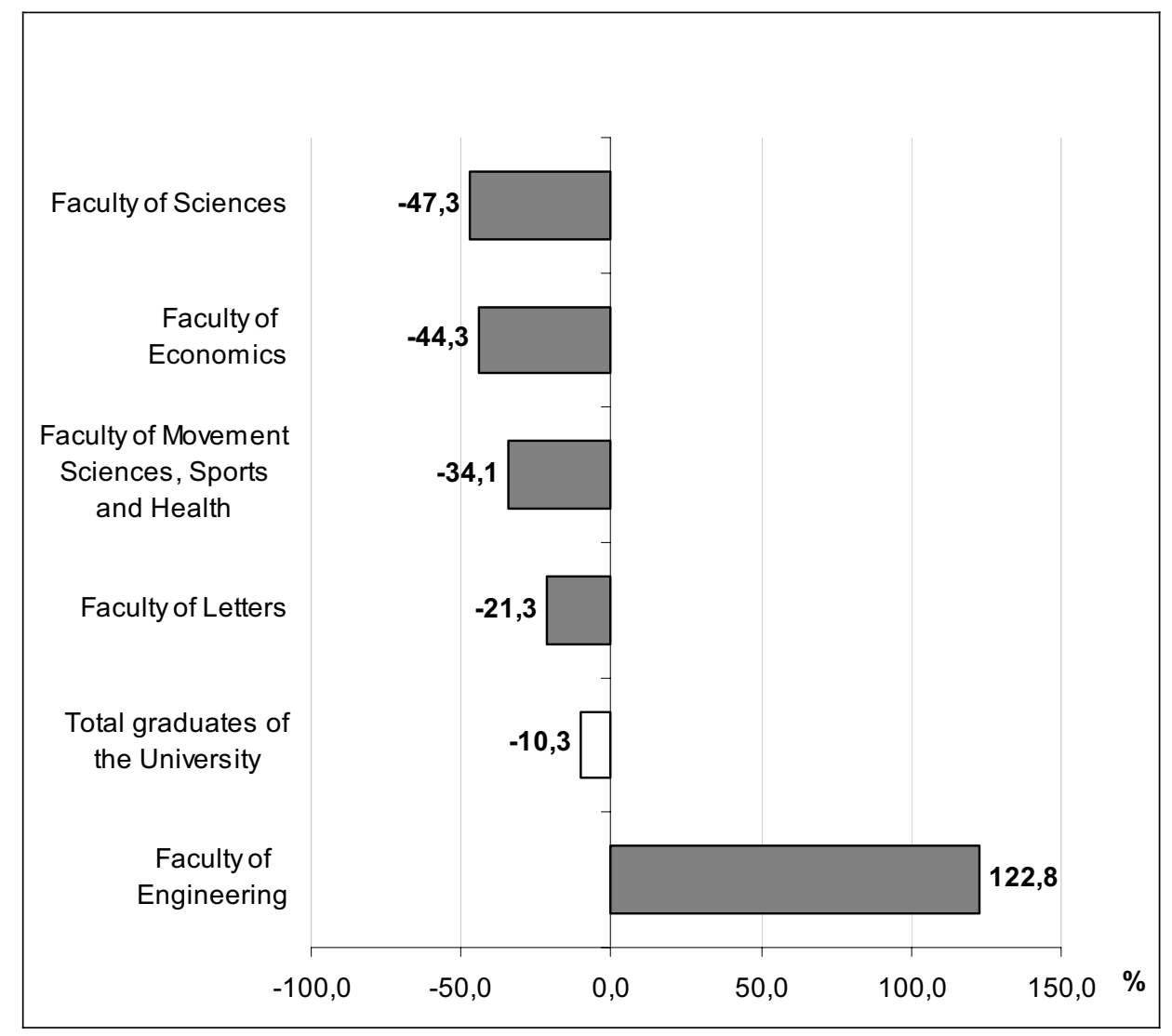

Figure 7. Dynamics in the number of graduates of the license programs at the end of the university year $2008 / 2009$ unlike $2007 / 2008$ ) $+/-\%$

Source: calculations after D.J.S data 
The share of the graduates in the total university respects the share of students, with the specific aspect mentioned before, of an increase in 2008 in the share of graduates for the Faculties of Economical Sciences of Movement, Sports and Health, and Letters, and in 2009 for the Faculty of Engineering.

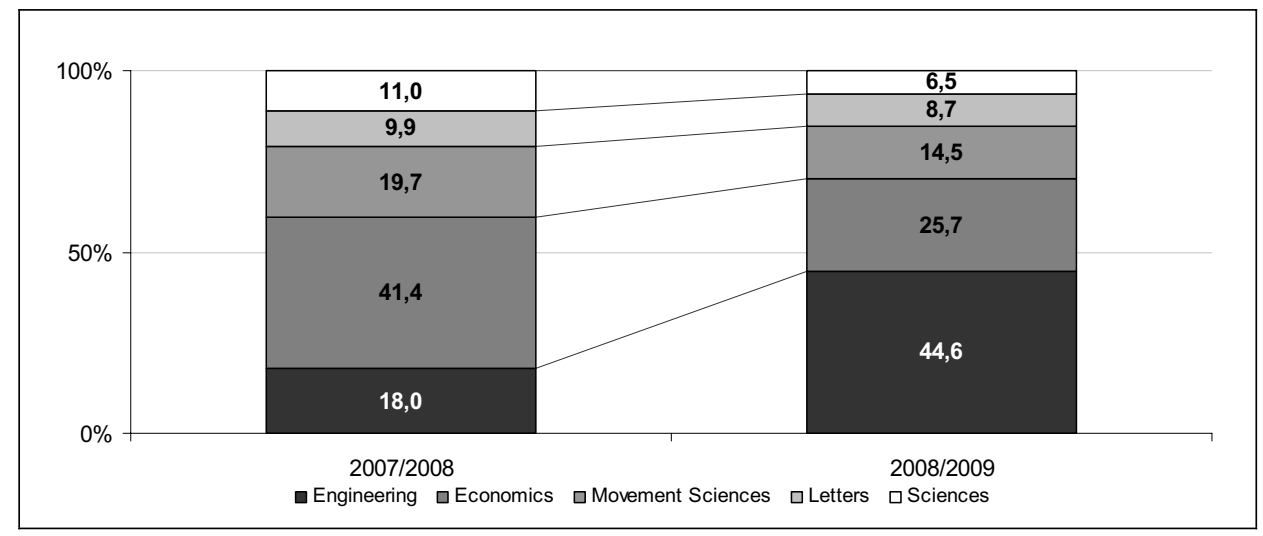

Figure. 8. Structure of the graduates of the license cycle,by faculties Source: calculations after D.J.S data

As noted in the analysis of the dynamics of statistical data, public higher education has diversified in both its specializations offered and the level of education, covering the license cycle, master, and in some specialties also the doctoral. The number of students enrolled has a positive dynamics, continuing the upward trend after the $90 \mathrm{~s}$. Better integration of graduates of public education university in Bacau into the labor market and the desire of many high school graduates to pursue a higher form of education, explains the high dynamics in the recent years.

The number of 7442 students in all forms of education points out clearly the university's increasing development in this regard. If we take into account the economic crisis and the demographic decline, factors acting generally in reducing the number of students, the university development appears stronger.

\section{Bibliografie}

1. Harja, E. (2009), Statistică şi Econometrie, Ed. Alma Mater, Bacău

2. Harja, E. (2010), Marketing, Raport de evaluare internă pe anul 2009 al C.R.D.F.C. al Universității „Vasile Alecsandri” Bacău

3. Jaba, E. (2005), Statistică, Ed. Economică, Bucureşti

4. Institutul Naţional de Statistică, (2009), Anuarul Statistic al României, București

5. www.ub.ro

6. $\quad$ www.insse.ro 